\title{
The Relationship between Emotional Intelligence and Hardiness on Stress Resistance in Athletes with Disabilities in Indonesian National Paralympic Committee
}

\author{
Muhammad Endra Sukmana \\ Postgraduate in Sports Science, Sebelas Maret University, Indonesia \\ Corresponding author email: sukmanaindra96@gmail.com \\ Agus Kristiyanto \\ Postgraduate in Sports Science, Sebelas Maret University, Indonesia \\ Email: agus_k@staff.uns.ac.id \\ Hanik Liskustyawati \\ Postgraduate in Sports Science, Sebelas Maret University, Indonesia \\ Email: honey_hany86@yahoo.com
}

\begin{abstract}
The purpose was to determine the relationship between emotional intelligence and hardiness on stress resistance in athletes with disabilities. This research is a quantitative approach. The data analysis technique using SPSS 22 16.0. The results can be concluded: (1) Emotional Intelligence and Stress Resistance, in athletes with disabilities with a total blindness correlation value of 0.450 with p. value or a significance of 0.062. (2) Emotional Intelligence and Stress Resistance, in athletes with disabilities with a low vision correlation value of 0.568 with $p$. value or a significance of 0.001. (3) Hardiness and Stress Resistance, in Athletes with Disabilities with a Blind correlation value of 0.638 with p. value or a significance of 0.002. (4) Hardiness and Stress Resistance in Athletes with Disabilities with Low Vision correlation value of 0.573 with p. value or a significance of 0.001. (5) Emotional Intelligence and Hardiness with Stress Resistance, in athletes with disabilities to Totally Blind r square of 0.495 with a significance value 0.002 which is less than 0.05. (6) Emotional Intelligence and Hardiness with Stress Resistance, in athletes with disabilities with low vision $r$ square of 0.420 with a significance value. 0.001 which is less than 0.05 . Keywords---athletes disabilities, emotional intelligence, hardiness, stress resistance.
\end{abstract}

\section{Introduction}

In long-term preparation, athletes with disabilities must attend a Training Center, this preparation is not as easy as most laypeople expect (Madden et al., 2017). The existence of training obligations and other rules that make attachment to athletes in it a stress factor for athletes with disabilities (DePauw, 1986). Phenomena like these are the reasons why athletes with disabilities feel bored while in training camps.

Not yet with the turmoil of situations that occur while at the training camp due to his condition or from his environment, for example, there is a less harmonious relationship between athletes and coaches or between other colleagues. This kind of condition can potentially cause stress to athletes with disabilities (Byers, 2015).

Stress can be experienced by any athlete, both athletes with hearing, visual impairments, and so on, and both men and women (Blumenstein \& Orbach, 2015). Because they are faced with the same thing, namely a routine of training with light to heavy intensity. So that each athlete has the ability or their way to deal with the stressors that come. The right response when dealing with stressors will cause a chain reaction towards improving the performance of athletes with disabilities during training camps, but if it is not addressed properly it will cause a decrease in the performance of athletes with disabilities and lead to degradation (McLoughlin et al., 2017). 
Stress is a condition that occurs as a result of internal and external pressure as well as other problematic conditions experienced by a person. Stress is a process that assesses an event as something that is threatening or dangerous and individuals respond to these events at the physiological, emotional, cognitive, and behavioral levels (Hanrahan, 2015). Training stress emphasizes athletes to a heavy and uncomfortable training condition and forms of disharmony between athletes and their environment. Many symptoms are caused by the stress of training experienced by athletes, the most common is feeling lazy and not serious in facing training, some of which are even looking for ways to miss training (Hutzler et al., 2013).

The more severe symptom of the wrong response is to itself, namely changes in diet and rest patterns so that it affects the decreased performance of the individual's training (Fitzgerald, 2012). All of these symptoms and effects are chain reactions of the individual's inappropriate response to stress. The stress that he experiences on an ongoing basis will interfere with his performance and result in his degradation at the national training camp to be replaced by other more potential athletes (Shapiro \& Martin, 2010; Shapiro \& Martin, 2014). Therefore, it is important for athletes who are undergoing training camps, especially athletes with disabilities, to have resistance to training stress during training sessions whose preparation is carried out in a relatively long time (Macdonald et al., 2016).

The formulation of stress resistance relies on three key elements. First, the ability to plan a positive action to limit and accommodate stress. Second, the ability to remain optimistic despite experiencing negative things or in dealing with sudden changes. Third, the ability to feel that we can control or cope with events that can cause stress (Holder, 2015).

Endurance to face training stress in athletes with disabilities on their ability to manage their souls, feelings, and characteristics, or more commonly called managing emotions is a form of emotional intelligence. Emotions are intense feelings aimed at someone or towards something as a form of reaction to someone or an event. Emotional Intelligence is a person's ability to manage an emotion so that it can solve problems with awareness according to thoughts and feelings. Emotional Intelligence includes self-control, enthusiasm, and self-motivation in aligning what is thought and what is felt to an action that is not harmful (Dehghansai et al., 2017).

It is important for an athlete, especially with certain privileges, to also have Emotional Intelligence in his efforts to be able to withstand situations and conditions that can cause stress when undergoing training concentration (Lane \& Wilson, 2011). Athletes with Emotional Intelligence can survive and bounce back when experiencing unpleasant conditions or those that make it worse so they can remain calm, concentrate and motivate themselves again to live what they have to do. A study by Lu et al. (2010), shows a positive correlation between Emotional Intelligence and the ability to deal with stress. In his research, he discussed the ability to deal with stress from the aspect of Emotional Intelligence (Filaire et al., 2011).

Other studies have found other aspects of personality types that make individuals resistant to stress. The individual personality type is Hardiness (Orbell et al., 2013). Hardiness is a personality variable that can explain individual differences in stress vulnerability (Salim et al., 2015). Individuals with high hardiness personalities have behaviors that make them stronger in facing work and other activities they enjoy and turn negative stressors into challenges, which means they become positive things (Sheard \& Golby, 2010; Delahaij et al., 2010).

In connection with the explanation above, in the context of athletes, especially with disabilities who are participating in training camps, they are prone to facing stressors that can test their psychological conditions. Starting from the intensity of exercise, the pressure in training, and things outside of training such as factors from the family, for example, the departure of relatives or others. Moreover, the burden of obligations as a national athlete is not something to play with, because it is responsible to family, society, and the state. Athletes with disabilities with certain tendencies will experience different difficulties in dealing with negative stressors (Goss, 1994). Hardiness does not only play a role in managing stress resistance in athletes but also has an impact on the psychological health of athletes who are undergoing long-term training concentration (Hanton et al., 2013). Commitment is a measure where a person shows individual involvement in his seriousness in doing something (Salim et al., 2016).

Commitment allows an athlete to have an understanding of what is his responsibility regarding what he is obliged to do when entering a training center. Moreover, on a national scale, its mission is to bring the name of the country to its responsibility so that it is obliged to show optimal performance either in training or later when undergoing a match. From the various discussions above, theoretically Emotional Intelligence and Hardiness, each of which has a relationship to resilience in the face of stress (Petrides \& Furnham, 2000; Palmer et al., 2002). Based on the background that the author has poured out, the researchers are interested in researching with the title, "the relationship between emotional intelligence and hardiness on stress resistance in athletes with visual disabilities in terms of visual impairment". 
Methods

The research was conducted at the Indonesian National Paralympic Committee Training Center based in the city of Surakarta, Central Java. This research is correlation research using a quantitative approach. This study using the purposive sampling technique. This study uses variables, among others, (1) Emotional Intelligence (X1), (2) Hardiness (X2), (3) Stress Resistance (Y), and (4) Visual Impairment. For Emotional Intelligence, hardiness is an independent variable or one that affects the dependent variable, namely stress resistance. Then Visual Impairment is an attributive variable to see the differences resulting from the independent and dependent variables.

The informants of this study were 52 athletes with blind disabilities who were in the Indonesian National Paralympic Committee, 22 total blind people, and 30 Low Vision athletes. Athletes with disabilities are spread across 5 sports, namely Blind Judo, Para-Athletic, Blind Chess, Goalball, and Para-Swimming. Data analysis techniques were carried out with the help of the program Statistical Product and Service Solution (SPSS) 22 for windows release 16.0. The instruments used were the Emotional Intelligence scale (The Schutte Self Report Emotional Intelligence Test/ SSEIT), the Hardiness Scale (Kobasa Hardiness Scale), and the Stress Resistance Scale (Connor DavidsonResilience Scale / CD-RISC).

\section{Results \\ Determination of research samples}

The study involved athletes with visual disabilities who tended towards the vision were blind and also those who still had little vision. For the sampling technique, researchers used purposive sampling, where the respondents have been determined and entered the criteria that the researcher wants to be based on the research objectives. The subjects in this study were athletes with visual disabilities, totaling 52 people and currently undergoing a national training camp. The following is an overview of research subjects in terms of age, sex, length of career, and based on their classification review.

Table 1

Distribution of research subject characteristics

\begin{tabular}{llll}
\hline & Subject & Amount & Percentage \\
\hline Age (Year) & $17-26$ & 33 & $63.46 \%$ \\
& $27-36$ & 12 & $23.08 \%$ \\
Gender & $\geqq 37$ & 7 & $13.46 \%$ \\
& Women Male & 19 & $36.54 \%$ \\
Career Length & & 33 & $63.46 \%$ \\
& $1-5$ Years & 26 & $50.00 \%$ \\
Classification & 6 - 10 Years & 17 & $32.69 \%$ \\
(Visual Impairment) & $\geqq 11$ Years & 9 & $17.31 \%$ \\
Total Athletes Overall & Low Vision & 22 & $42.31 \%$ \\
\hline
\end{tabular}

From what has been stated in the table above, it can be seen that for the distribution of research data based on the age range is 33 people or $63.46 \%$ are in the range $17-26$ years, 12 people or $23.08 \%$ are in the range $27-36$ years and 7 people or $13.46 \%$ aged 37 years and over. Based on gender, as many as 19 people, or $36.54 \%$ were female and 33 people, or $63.46 \%$ were males. Based on career length, as many as 26 athletes or $50 \%$ were in the $1-5$ years range, 17 athletes or $32.69 \%$ were in the 6-10 years range and the remaining 9 people or $17.31 \%$ had worked for 11 years or more. Then in terms of classification, as many as 22 athletes or $42.31 \%$ had a Blind classification and 30 athletes or $57.69 \%$ had a Low Vision classification.

\section{Descriptive analysis results}

This research was conducted on athletes with visual disabilities with a tendency to Totally Blind (Complete Blind) and Low Vision (Partially Blind), and are currently exploring the National Training Center in Surakarta with a total sample size of 52 athletes. The results data in this study were obtained based on test scores that have been carried out 
using a measuring scale, including tests of Emotional Intelligence, Hardiness, and Stress Resistance. Descriptive analysis in this study includes the number of research subjects $(\mathrm{N})$, mean $(\pi)$, standard deviation (SD), variance (s2), lowest score (X min), and the highest score (X max) and other statistics. The recording of the results of the research that has been carried out obtains the data presented in descriptive form as in the following table:

Table 2

Description of research data

\begin{tabular}{|c|c|c|c|c|c|c|}
\hline Subject & $\mathrm{N}$ & Research Variable & $X_{\min }$ & $X_{\max }$ & Mean & $\mathrm{SD}$ \\
\hline \multirow[t]{3}{*}{ Totally Blind } & 22 & Emotional intelligence & 80 & 94 & 87.18 & 4.12 \\
\hline & & Hardiness & 44 & 50 & 47.23 & 1.82 \\
\hline & & Stress Resistance & 70 & 87 & 78.77 & 4.55 \\
\hline \multirow[t]{3}{*}{ Low Vision } & 30 & Emotional intelligence & 78 & 97 & 89.50 & 5.02 \\
\hline & & Hardiness & 40 & 55 & 48.17 & 3.50 \\
\hline & & Stress Resistance & 72 & 86 & 78.53 & 4.14 \\
\hline
\end{tabular}

Scale overview

a) Emotional Intelligence Scale

The analysis that researchers use in the Emotional Intelligence scale is to use categorization according to the normal distribution model. Based on the data obtained, the results are then classified into three categories, using a formula as shown in the following table:

Table 3

Classification of emotional intelligence score criteria

\begin{tabular}{lll}
\hline Number & Interval & Criteria \\
\hline 1 & $\mathrm{X}<\pi-1 \alpha$ & Low \\
2 & $\pi-1 \alpha \geqq \mathrm{X}<\pi+1 \alpha$ & Moderate \\
3 & $\mathrm{X} \geqq \pi+1 \alpha$ & High \\
\hline
\end{tabular}

Measurements were made using a Likert scale against 30 valid items. With information, the subject has low criteria if the score obtained is lower than the average minus one standard deviation, the subject has moderate criteria if the score obtained is greater than the average score minus one standard deviation and is smaller than the average in plus one standard deviation, the subject has high criteria if the score obtained is greater than the average plus one standard deviation.

1) Athletes with visual disabilities with a tendency to Totally Blind

The results of the Emotional Intelligence frequency distribution data for blind athletes with a tendency to Totally Blind or completely blind can be seen in the following table:

Table 4

Emotional intelligence frequency distribution in blind athletes

\begin{tabular}{lllll}
\hline Number & Interval & Criteria & Frequency & Percentage \\
\hline 1 & $\mathrm{X}<83$ & Low & 3 & $13.64 \%$ \\
2 & $83 \geqq \mathrm{X}<91$ & Moderate & 13 & $59.09 \%$ \\
3 & $\mathrm{X} \geqq 91$ & High & 6 & $27.27 \%$ \\
Total & & & 22 & $100 \%$ \\
\hline
\end{tabular}

From the research data on the Emotional Intelligence scale that has been scoring on athletes with blind disabilities with a tendency to Totally Blind, it is known that as many as 3 or $13.64 \%$ of subjects have Emotional Intelligence which is in the low category. As many as 13 or $59.09 \%$ of subjects have Emotional 
Intelligence which is in the medium category. Then the rest, which is 6 or $27.27 \%$ of the subjects have Emotional Intelligence which is in the high category.

2) Athletes with visual disabilities with Low Vision tendencies

The results of the Emotional Intelligence frequency distribution data for blind athletes with low vision or partial blindness can be seen in the following table:

Table 5

Emotional intelligence frequency distribution in low vision athletes

\begin{tabular}{lllll}
\hline Number & Interval & Criteria & Frequency & Percentage \\
\hline 1 & $\mathrm{X}<84$ & Low & 4 & $13.33 \%$ \\
2 & $84 \geqq \mathrm{X}<95$ & Moderate & 22 & $73.34 \%$ \\
3 & $\mathrm{X} \geqq 95$ & High & 4 & $13.33 \%$ \\
Total & & & 30 & $100 \%$ \\
\hline
\end{tabular}

From the research data on the Emotional Intelligence scale that has been scoring on athletes with low vision disabilities, it is known that as many as 4 or $13.33 \%$ of subjects have Emotional Intelligence which is in the low category. As many as 22 or $73.34 \%$ of subjects had Emotional Intelligence which was in the medium category. Then the rest, namely 4 or $13.33 \%$ of subjects have Emotional Intelligence which is in the high category.

b) Hardiness Scale

The analysis that researchers use in the Hardiness scale is to use categorization according to the normal distribution model. Measurements were made using a Likert scale against 15 valid items. With information, the subject has low criteria if the score obtained is lower than the average minus one standard deviation, the subject has moderate criteria if the score obtained is greater than the average score minus one standard deviation and is smaller than the average in plus one standard deviation, the subject has high criteria if the score obtained is greater than the average plus one standard deviation. Based on the data obtained, the results are then classified into three categories, using a formula as shown in the following table:

Table 6

Hardiness score criteria classification

\begin{tabular}{lll}
\hline Number & Interval & Criteria \\
\hline 1 & $\mathrm{X}<\pi-1 \alpha$ & Low \\
2 & $\pi-1 \alpha \geqq \mathrm{X}<\pi+1 \alpha$ & Moderate \\
3 & $\mathrm{X} \geqq \pi+1 \alpha$ & High \\
\hline
\end{tabular}

1) Athletes with visual disabilities with a tendency to Totally Blind

The results of the hardiness frequency distribution data on athletes with visual disabilities with a tendency to Totally Blind or completely blind can be seen in the following table:

Table 7

Distribution of hardiness frequency in totally blind athletes

\begin{tabular}{lllll}
\hline Number & Interval & Criteria & Frequency & Percentage \\
\hline 1 & $\mathrm{X}<45$ & Low & 1 & $4.54 \%$ \\
2 & $45 \geqq \mathrm{X}<49$ & Moderate & 14 & $63.64 \%$ \\
3 & $\mathrm{X} \geqq 49$ & High & 7 & $31.82 \%$ \\
Total & & & 22 & $100 \%$ \\
\hline
\end{tabular}

From the data on the Hardiness scale research that has been scored on athletes with blind disabilities with a tendency to Totally Blind, it is known that as much as 1 or $4.54 \%$ of subjects have hardiness which is in the low category. A total of 14 or $63.64 \% \%$ of subjects had Hardiness which was in the moderate category. Then the rest, namely as many as 7 or $31.82 \%$ of the subjects have hardiness which is in the high category. 
2) Athletes with visual disabilities with Low Vision tendencies

The results of hardiness frequency distribution data on blind athletes with low vision or partial blindness can be seen in the following table:

Table 8

Distribution of hardiness frequency in low vision athletes

\begin{tabular}{llllc}
\hline Number & Interval & Criteria & Frequency & Percentage \\
\hline 1 & $\mathrm{X}<45$ & Low & 4 & $13.33 \%$ \\
2 & $45 \geqq \mathrm{X}<52$ & Moderate & 21 & $70.00 \%$ \\
3 & $\mathrm{X} \geqq 52$ & High & 5 & $16.67 \%$ \\
Total & & & 30 & 100 \\
\hline
\end{tabular}

From the research data on the Hardiness scale that has been scoring the athletes with low vision with a tendency towards a low vision, it is known that as many as 4 or $13.33 \%$ of the subjects have hardiness which is in the low category. As many as 21 or $70.00 \%$ of subjects have Hardiness which is in the moderate category. Then the rest, namely 5 or $16.67 \%$ of subjects have hardiness which is in the high category.

c) Stress Resistance Scale

The analysis that researchers use in the Stress Resistance scale is to use categorization according to the normal distribution model. Measurements were made using a Likert scale against 25 valid items. With information, the subject has low criteria if the score obtained is lower than the average minus one standard deviation, the subject has moderate criteria if the score obtained is greater than the average score minus one standard deviation and is smaller than the average in plus one standard deviation, the subject has high criteria if the score obtained is greater than the average plus one standard deviation. Based on the data obtained, the results are then classified into three categories, using a formula as shown in the following table:

Table 9

Classification of stress resistance score criteria

\begin{tabular}{lll}
\hline Number & Interval & Criteria \\
\hline 1 & $\mathrm{X}<\pi-1 \alpha$ & Low \\
2 & $\pi-1 \alpha \geqq \mathrm{X}<\pi+1 \alpha$ & Moderate \\
3 & $\mathrm{X} \geqq \pi+1 \alpha$ & High \\
\hline
\end{tabular}

1) Athletes with visual disabilities with a tendency to Totally Blind

The results of the Stress Endurance frequency distribution data for blind athletes with a tendency to Totally Blind or completely blind can be seen in the following table:

Table 10

Stress resistance frequency distribution in totally blind athletes

\begin{tabular}{lllll}
\hline Number & Interval & Criteria & Frequency & Percentage \\
\hline 1 & $\mathrm{X}<74$ & Low & 3 & $13.64 \%$ \\
2 & $74 \geqq \mathrm{X}<83$ & Moderate & 15 & $68.18 \%$ \\
3 & $\mathrm{X} \geqq 83$ & High & 4 & $18.18 \%$ \\
Total & & & 22 & $100 \%$ \\
\hline
\end{tabular}

From the research data on the Stress Endurance scale that has been scored on athletes with blind disabilities with a tendency to Totally Blind, it is known that as many as 3 or $13.64 \%$ of subjects have Stress Resistance which is in the low category. As many as 15 or $68.18 \%$ of subjects had Stress Resistance in the moderate category. Then the rest, namely 4 or $18.18 \%$ of subjects have Stress Resistance which is in the high category. 
2) Athletes with visual disabilities with Low Vision tendencies

The results of the frequency distribution of Stress Endurance in athletes with visual disabilities with low vision or partial blindness can be seen in the following table:

Table 10

Stress endurance frequency distribution in low vision athletes

\begin{tabular}{lllll}
\hline Number & Interval & Criteria & Frequency & Percentage \\
\hline 1 & $\mathrm{X}<74$ & Low & 3 & $10.00 \%$ \\
2 & $74 \geqq \mathrm{X}<83$ & Moderate & 21 & $70.00 \%$ \\
3 & $\mathrm{X} \geqq 83$ & High & 6 & $20.00 \%$ \\
Total & & & 30 & $100 \%$ \\
\hline
\end{tabular}

From the research data on the Stress Endurance scale that has been scored on athletes with visual disabilities with low vision tendencies, it is known that as many as 3 or $10 \%$ of the subjects have Stress Resistance in the low category. As many as 21 or $70 \%$ of subjects had Stress Resistance in the moderate category. Then the rest, namely as many as 6 or $20 \%$ of subjects have Stress Resistance which is in the high category.

Test prerequisite analysis

a. Normality test

1) Results of Totally Blind Athlete Data Analysis

Table 11

Kolmogorov-Smirnov Test Data Blind Athletes

\begin{tabular}{|c|c|c|}
\hline \multicolumn{3}{|c|}{ One-Sample Kolmogorov-Smirnov Test } \\
\hline & & Unstandardized \\
\hline & & Residual \\
\hline \multicolumn{2}{|c|}{$\mathrm{N}$} & 22 \\
\hline \multirow{3}{*}{ Normal Parameters a,b } & Mean & .0000000 \\
\hline & Std. Deviation & 3.23134421 \\
\hline & Absolute & .134 \\
\hline \multirow[t]{2}{*}{ Most Extreme Differences } & Positive & .099 \\
\hline & Negative & -.134 \\
\hline Test Statistic & & .134 \\
\hline Asymp. Sig. (2-tailed) & & $.200 \mathrm{c}, \mathrm{d}$ \\
\hline
\end{tabular}

The test involved independent variables, namely Emotional Intelligence and Hardiness, and Dependent variables, namely Stress Resistance with a sample size of 22 athletes with a tendency to Totally Blind (Complete Blind). Based on the normality test using the Kolmogorov-Smirnov Test technique, it is known that the significance value is 0.200 , or more $>0.05$, so it can be concluded that the data residual value of Blind Athletes is normally distributed.

2) Results of Data Analysis for Low Vision Athletes

Table 12

Kolmogorov-Smirnov Test Data Test for Low Vision Athletes

\begin{tabular}{|c|c|c|}
\hline \multicolumn{3}{|c|}{ One-Sample Kolmogorov-Smirnov Test } \\
\hline$x^{2}$ & 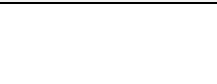 & $\begin{array}{c}\text { Unstandardized } \\
\text { Residual }\end{array}$ \\
\hline 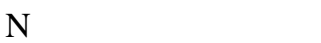 & & 30 \\
\hline \multirow{2}{*}{ Normal Parameters a,b } & Mean & .0000000 \\
\hline & Std. Deviation & 3.15437722 \\
\hline Most Extreme & Absolute & .163 \\
\hline
\end{tabular}




\begin{tabular}{llr}
\hline Differences & Positive & .112 \\
& Negative & -.163 \\
Test Statistic & & .163 \\
Asymp. Sig. (2-tailed) & & $.140^{\mathrm{c}, \mathrm{d}}$ \\
\hline
\end{tabular}

The test involved independent variables, namely Emotional Intelligence and Hardiness, and Dependent variables, namely Stress Resistance with a sample of 30 athletes with a tendency to Low Vision (Partially Blind). Based on the normality test using the Kolmogorov-Smirnov Test technique, it is known that the significance value is 0.140 , or more $>0.05$, so it can be concluded that the data residual value of Blind Athletes is normally distributed.

b. Linearity Test

1) Results of Totally Blind Athlete Data Linearity Test

Table 13

Totally blind athlete data linearity test

\begin{tabular}{|c|c|c|c|c|c|c|c|}
\hline \multicolumn{8}{|c|}{ ANOVA Table } \\
\hline & & & $\begin{array}{l}\text { Sum of } \\
\text { Squares }\end{array}$ & df & $\begin{array}{l}\text { Mean } \\
\text { Square }\end{array}$ & $\mathrm{F}$ & Sig. \\
\hline \multirow{5}{*}{$\begin{array}{l}\text { Unstandardized } \\
\text { Residual * } \\
\text { Unstandardized } \\
\text { Predicted Value }\end{array}$} & Between & (Combined) & 160.273 & 18 & 8.904 & .453 & .878 \\
\hline & Groups & Linearity & .000 & 1 & .000 & .000 & 1.000 \\
\hline & & $\begin{array}{l}\text { Deviation from } \\
\text { Linearity }\end{array}$ & 160.273 & 17 & 9.428 & .479 & .860 \\
\hline & \multicolumn{2}{|c|}{ Within Groups } & 59.000 & 3 & 19.667 & & \\
\hline & Total & & 219.273 & 21 & & & \\
\hline
\end{tabular}

Based on the test results, it shows that the significance value is 1.00 , the value is $>0.05$, so it can be concluded that the data variables of the Totally Blind athlete include independent variables, namely, Emotional Intelligence and Hardiness, which have a linear relationship to the dependent variable, namely Stress Resistance.

2) Linearity Test Results for Low Vision Athletes Data

Table 14

Linearity test of low vision athlete data

\begin{tabular}{|c|c|c|c|c|c|c|c|}
\hline \multicolumn{8}{|c|}{ ANOVA Table } \\
\hline & & & $\begin{array}{l}\text { Sum of } \\
\text { Squares }\end{array}$ & $\mathrm{df}$ & $\begin{array}{l}\text { Mean } \\
\text { Square }\end{array}$ & $\mathrm{F}$ & Sig. \\
\hline \multirow{5}{*}{$\begin{array}{l}\text { Unstandardized } \\
\text { Residual * } \\
\text { Unstandardized } \\
\text { Predicted Value }\end{array}$} & Between & (Combined) & 268.053 & 26 & 10.310 & 1.509 & .418 \\
\hline & Groups & Linearity & .000 & 1 & .000 & .000 & 1.000 \\
\hline & & $\begin{array}{l}\text { Deviation from } \\
\text { Linearity }\end{array}$ & 268.053 & 25 & 10.722 & 1.569 & 402 \\
\hline & \multicolumn{2}{|c|}{ Within Groups } & 20.500 & 3 & 6.833 & & \\
\hline & \multicolumn{2}{|l|}{ Total } & 288.553 & 29 & & & \\
\hline
\end{tabular}


1. Hypothesis Testing

a. Product Moment Correlation Analysis

1) Results of Totally Blind Athlete Data Analysis

Table 15

Totally blind product-moment data correlation test

\begin{tabular}{clrll}
\hline Number & Variable & rxy & Sig value. & Information \\
\hline 1 & $\begin{array}{l}\text { Emotional Intelligence (X1) on } \\
\text { Stress Resistance (Y) }\end{array}$ & 0.450 & 0.062 & $\begin{array}{l}\text { There is no significant } \\
\text { relationship }\end{array}$ \\
2 & $\begin{array}{l}\text { Hardiness (X2) on Stress } \\
\text { Resistance (Y) }\end{array}$ & 0.638 & 0.001 & $\begin{array}{l}\text { There is a positive and } \\
\text { significant relationship }\end{array}$ \\
\hline
\end{tabular}

The results of testing the first Totally Blind athlete data, namely the relationship between Emotional Intelligence and stress resistance, obtained a rxy value of 0.45 with a p.value or a significance value of 0.062 so that sig. $>0.05$ means that there is no relationship between Emotional Intelligence and stress resistance. This means that high and low Emotional Intelligence possessed by athletes with visual disabilities with a tendency to Totally Blind, does not affect stress resistance. It is concluded that the hypothesis in this study is rejected.

The second test result, namely between hardiness and stress resistance, obtained a rxy value of 0.638 with a p.value or a significance value of 0.001 so that sig. $<0.05$ means that there is a positive and significant relationship between Hardiness and Stress Resistance. This means that the higher the Hardiness a Totally Blind athlete has, the higher his endurance in dealing with stress. It is concluded that the second hypothesis in this study is accepted.

2) Results of Low Vision Athlete Data Analysis

Table 16

Low vision product moment data correlation test

\begin{tabular}{cllll}
\hline Number & Variable & rxy & Sig value. & Information \\
\hline 1 & $\begin{array}{l}\text { Emotional Intelligence (X1) on } \\
\text { Stress Resistance (Y) }\end{array}$ & 0.568 & 0.001 & $\begin{array}{l}\text { There is a positive and } \\
\text { significant relationship }\end{array}$ \\
2 & $\begin{array}{l}\text { Hardiness (X2) on Stress } \\
\text { Resistance (Y) }\end{array}$ & 0.638 & 0.001 & $\begin{array}{l}\text { There is a positive and } \\
\text { significant relationship }\end{array}$ \\
\hline
\end{tabular}

The results of testing the data for the first Low Vision athletes, namely the relationship between Emotional Intelligence and stress resistance, obtained a rxy value of 0.568 with a p.value or a significance value of 0.001 so that sig. $<0.05$ means that there is a positive and significant relationship between Emotional Intelligence and Stress Resistance. This means that the higher the Emotional Intelligence possessed by Low Vision athletes, the higher their endurance in dealing with stress. It is concluded that the hypothesis in this study is accepted.

The second test result, namely between hardiness and stress resistance, obtained a rxy value of 0.573 with a p.value or a significance value of 0.001 so that sig. $<0.05$ means that there is a positive and significant relationship between Hardiness and Stress Resistance. This means that the higher the hardiness possessed by Low Vision athletes, the higher their endurance in dealing with stress.

b. Multiple Correlation Analysis

1) Multiple Correlation Test of Totally Blind Athlete Data 
Table 17

Multiple correlation test for totally blind athletes

\begin{tabular}{|c|c|c|c|c|c|c|c|c|c|}
\hline \multirow[b]{3}{*}{ Model } & \multicolumn{8}{|c|}{ Model Summary } & \\
\hline & \multirow[b]{2}{*}{$\mathrm{R}$} & \multirow[b]{2}{*}{$\begin{array}{c}\mathrm{R} \\
\text { Square }\end{array}$} & \multirow[b]{2}{*}{$\begin{array}{l}\text { Adjusted } \\
\text { R Square }\end{array}$} & \multirow{2}{*}{$\begin{array}{l}\text { Std. Error } \\
\text { of the } \\
\text { Estimate }\end{array}$} & \multicolumn{5}{|c|}{ Change Statistics } \\
\hline & & & & & $\begin{array}{l}\text { R Square } \\
\text { Change }\end{array}$ & $\begin{array}{c}\mathrm{F} \\
\text { Change }\end{array}$ & df1 & df2 & $\begin{array}{c}\text { Sig. F } \\
\text { Change }\end{array}$ \\
\hline 1 & $.703^{\mathrm{a}}$ & .495 & .441 & 3.397 & .495 & 9.297 & 2 & 1 & .002 \\
\hline
\end{tabular}

a. Predictors: (Constant), Hardiness, Emotional Intelligence

The results of the multiple correlation test of Totally Blind Athlete Data, namely between Emotional Intelligence and Hardiness on stress resistance, obtained a value of rx $1 \mathrm{x} 2 \mathrm{y}$ of 0.703 with a significance value of 0.002 so that sig. $<0.05$. This shows that there is a strong correlation between Emotional Intelligence and Hardiness with Stress Resistance. So that the hypothesis in this study is accepted.

2) Multiple Correlation Test of Low Vision Athlete Data

Table 18

Multiple correlation test for low vision athletes

\begin{tabular}{|c|c|c|c|c|c|c|c|c|c|}
\hline \multicolumn{10}{|c|}{ Model Summary } \\
\hline \multirow[b]{2}{*}{ Model } & \multirow[b]{2}{*}{$\mathrm{R}$} & \multirow[b]{2}{*}{ R Square } & \multirow[b]{2}{*}{$\begin{array}{l}\text { Adjusted } \\
\text { R Square }\end{array}$} & \multirow{2}{*}{$\begin{array}{l}\text { Std. Error } \\
\text { of the } \\
\text { Estimate }\end{array}$} & \multicolumn{5}{|c|}{ Change Statistics } \\
\hline & & & & & $\begin{array}{l}\text { R Square } \\
\text { Change }\end{array}$ & F Change & df1 & df2 & $\begin{array}{c}\text { Sig. F } \\
\text { Change }\end{array}$ \\
\hline 1 & $.648^{\mathrm{a}}$ & .420 & .377 & 3.269 & .420 & 9.774 & 2 & 27 & .001 \\
\hline
\end{tabular}

a. Predictors: (Constant), Hardiness, Emotional Intelligence

The results of the multiple correlation test of Low Vision Athlete Data, namely between Emotional Intelligence and Hardiness on stress resistance, obtained a value of $\mathrm{rx} 1 \mathrm{x} 2 \mathrm{y}$ of 0.648 with a significance value of 0.001 so that sig. $<0.05$. This shows that there is a strong correlation between Emotional Intelligence and Hardiness with Stress Resistance. So that the hypothesis in this study is accepted.

c. Multiple Linear Regression Analysis

1) Correlation test multiple linear regression data Totally Blind Athletes

Table 19

Totally blind athlete multiple linear regression test

\begin{tabular}{|c|c|c|c|c|c|c|}
\hline \multicolumn{7}{|c|}{ Coefficients $^{\mathrm{a}}$} \\
\hline \multirow{2}{*}{\multicolumn{2}{|c|}{ Model }} & \multicolumn{2}{|c|}{$\begin{array}{l}\text { Unstandardized } \\
\text { Coefficients }\end{array}$} & \multirow{2}{*}{$\begin{array}{c}\text { Standardized } \\
\text { Coefficients } \\
\text { Beta }\end{array}$} & \multirow[b]{2}{*}{$\mathrm{t}$} & \multirow[b]{2}{*}{ Sig. } \\
\hline & & B & Std. Error & & & \\
\hline \multirow[t]{3}{*}{1} & (Constant) & -18.629 & 22.813 & & -.817 & .424 \\
\hline & Emotional Intelligence & .329 & .182 & .300 & 1.810 & .086 \\
\hline & Hardiness & 1.457 & .413 & .584 & 3.525 & .002 \\
\hline
\end{tabular}

a. Dependent Variable: Daya Tahan Stres

The regression coefficient value of the Emotional Intelligence (X1) variable for Totally Blind athletes is 0.329, so if there is an increase in the Emotional Intelligence (X1) aspect, it will affect the Stress Endurance (Y) ability of Totally Blind athletes of 0.329 . The regression coefficient value of the Hardiness (X2) variable for Totally Blind athletes is 1.457, so if there is an increase in the Hardiness (X2) aspect, it will affect the Stress Resistance (Y) ability of Totally Blind athletes of 1.457. 
2) Multiple linear regression correlation test for Low Vision Athlete Data

Table 20

Multiple linear regression test for low vision athletes

\begin{tabular}{|c|c|c|c|c|c|c|}
\hline \multirow[b]{2}{*}{ Model } & & \multicolumn{2}{|c|}{$\begin{array}{c}\text { Unstandardized } \\
\text { Coefficients }\end{array}$} & $\begin{array}{l}\text { Standardized } \\
\text { Coefficients }\end{array}$ & \multirow[b]{2}{*}{$\mathrm{t}$} & \multirow[b]{2}{*}{ Sig. } \\
\hline & & B & Std. Error & Beta & & \\
\hline \multirow[t]{3}{*}{1} & (Constant) & 30.491 & 11.218 & & 2.718 & .011 \\
\hline & Emotional Intelligence & .299 & .145 & .362 & 2.061 & .049 \\
\hline & Hardiness & .442 & 207 & .374 & 2.132 & .042 \\
\hline
\end{tabular}

a. Dependent Variable: Daya Tahan Stres

d. Model Significance Test

1) Significance Test of Totally Blind Athlete Model

Table 21

Significance test of totally blind athlete model

\begin{tabular}{llrrrrr}
\hline \multicolumn{7}{c}{ ANOVA $^{\mathrm{a}}$} \\
\hline Model & & Sum of Squares & $\mathrm{df}$ & Mean Square & \multicolumn{1}{c}{ F } & Sig. \\
\hline 1 & Regression & 214.590 & 2 & 107.295 & 9.297 & $.002^{\mathrm{b}}$ \\
& Residual & 219.273 & 19 & 11.541 & & \\
& Total & 433.864 & 21 & & & \\
\hline
\end{tabular}

a. Dependent Variable: Daya Tahan Stres

b. Predictors: (Constant), Hardiness, Emotional Intelligence

The results obtained show an $\mathrm{F}$ value of 9,297 with a significance value of 0.002 , so $\mathrm{P}<0.05$, which means that the regression is linear and the results obtained are valid to make conclusions about the relationship of the variables being studied, namely between Emotional Intelligence (X1) and Hardiness. (X2) with Stress Resistance.

2) Significance Test of Low Vision Athlete Model

Table 22

Significance test of low vision athlete model

\begin{tabular}{llrrrrr}
\hline \multicolumn{7}{c}{ ANOVA $^{\mathrm{a}}$} \\
Model & & Sum of Squares & df & Mean Square & F & Sig. \\
\hline 1 & Regression & 208.914 & 2 & 104.457 & 9.774 & $.001^{\mathrm{b}}$ \\
& Residual & 288.553 & 27 & 10.687 & & \\
& Total & 497.467 & 29 & & & \\
\hline
\end{tabular}

a. Dependent Variable: Daya Tahan Stres

b. Predictors: (Constant), Hardiness, Emotional Intelligence

The results obtained show an $\mathrm{F}$ value of 9,774 with a significance value of 0.001 so that $\mathrm{P}<0.05$, which means that the regression is linear and the results obtained are validly used to make conclusions about the relationship of the variables being studied, namely between Emotional Intelligence (X1) and Hardiness. (X2) with Stress Resistance.

e. Determination Analysis (R2 Test)

1) Data determination test for Totally Blind Athletes 
Table 23

Data determination test on Totally Blind Athletes

\begin{tabular}{cllll}
\hline Number & \multicolumn{1}{c}{ Variable } & rxy & \multicolumn{1}{c}{$\begin{array}{c}\mathrm{r}^{2} \\
(\mathrm{r} \text { square value })\end{array}$} & \multicolumn{1}{c}{ Persentase } \\
\hline 1 & $\begin{array}{l}\text { Emotional Intelligence (X1) on } \\
\text { Stress Resistance (Y) }\end{array}$ & 0.450 & 0.180 & $18.00 \%$ \\
2 & $\begin{array}{l}\text { Hardiness (X2) on Stress } \\
\text { Resistance (Y) }\end{array}$ & 0.638 & 0.407 & $40.70 \%$ \\
\hline
\end{tabular}

Based on the presentation of the table above, it is known that the $\mathrm{r} 2$ ( $\mathrm{r}$ square value) of the Emotional Intelligence (X1) variable on Stress Resistance $(\mathrm{Y})$ is 0.180. This shows that the Emotional Intelligence variable (X1) has an influence or contributes to Stress Resistance $(\mathrm{Y})$ by $18.00 \%$. The value of $\mathrm{r} 2$ (r square value) of the Hardiness variable (X2) on Stress Resistance (Y) is 0.407 . This shows the meaning that the Hardiness variable (X2) has an influence or contributes to Stress Resistance (Y) by $40.70 \%$. The r2 value (r square value) between Emotional Intelligence (X1) and Hardiness (X2) on Stress Resistance (Y) as a whole is 0.495. So that the influence or contribution of Emotional Intelligence (X1) and Hardiness (X2) on Stress Resistance (Y) is $49.50 \%$ and the remaining $50.50 \%$ is influenced by other factors that are not studied and described in this study.

2) Data determination test for Low Vision Athletes

Table 24

Low vision athlete data determination test

\begin{tabular}{cllll}
\hline \multirow{2}{*}{ Number } & \multicolumn{1}{c}{ Variable } & rxy & $\begin{array}{c}\mathrm{r}^{2} \\
(\mathrm{r} \text { square value) }\end{array}$ & \multicolumn{1}{c}{ Persentase } \\
\hline 1 & $\begin{array}{l}\text { Emotional Intelligence (X1) on } \\
\text { Stress Resistance (Y) }\end{array}$ & 0.568 & 0.322 & $32.23 \%$ \\
2 & $\begin{array}{l}\text { Hardiness (X2) on Stress } \\
\text { Resistance (Y) }\end{array}$ & 0.638 & 0.329 & $32.90 \%$ \\
\hline
\end{tabular}

Based on the presentation of the table above, it is known that the $\mathrm{r} 2$ ( $\mathrm{r}$ square value) of the Emotional Intelligence (X1) variable on Stress Resistance (Y) is 0.322. This shows that the Emotional Intelligence (X1) variable has an influence or contributes to Stress Resistance $(\mathrm{Y})$ by 32.23\%. The value of $\mathrm{r} 2$ ( $\mathrm{r}$ square value) of the Hardiness variable (X2) on Stress Resistance (Y) is 0.329. This shows the meaning that the Hardiness variable (X2) has an influence or contributes to Stress Resistance (Y) by $32.90 \%$. The value of $\mathrm{r} 2$ (r square value) between Emotional Intelligence (X1) and Hardiness (X2) on Stress Resistance (Y) as a whole is 0.420. So that the influence or contribution of Emotional Intelligence (X1) and Hardiness (X2) on Stress Resistance $(\mathrm{Y})$ is $42.00 \%$ and the remaining $58.00 \%$ is influenced by other factors that are not studied and described in this study.

\section{Discussion}

1. Relationship and Contribution or Influence of Emotional Intelligence with Stress Resistance

Based on the results of data analysis obtained between the Emotional Intelligence variable and Stress Endurance, the correlation between athletes with visual disabilities and the tendency of Totally Blind is 0.450 with a significance value of 0.062 . It is concluded that there is no significant relationship between Emotional Intelligence and stress endurance in totally blind athletes. However, it has a partial contribution or influence, indicated by the amount of $r$ square ( $r 2$ ) which is 0.180 or $18 \%$. The linear regression coefficient value shows the value of 0.329 with a positive sign, meaning that if there is an increase in the Emotional Intelligence variable, it will increase stress resistance by 0.329 . So it can be concluded that the research hypothesis is rejected.

The results of data analysis obtained between the Emotional Intelligence variable and Stress Endurance, for athletes with visual disabilities with low vision tendencies, the correlation results are 0.568 with a significance 
value of 0.001. It was concluded that Emotional Intelligence and stress endurance in Low Vision athletes had a significant relationship. For the partial contribution or influence, it is indicated by the amount of $r$ square (r2) obtained by 0.322 or $32.23 \%$. The linear regression coefficient value shows the value of 0.0 .229 with a positive sign, meaning that if there is an increase in the Emotional Intelligence variable, it will increase stress resistance by 0.329 . So that the overall hypothesis in this study is accepted.

The results of the data analysis in this study indicate that one of the psychological factors possessed, namely Emotional Intelligence, has a role or is an element that is no less important in the stress resistance of athletes with visual disabilities. Emotional Intelligence is needed so that a person can control various things from within himself to be able to display the best thing, in this case, for example, managing emotions, regulating mood so that this will have an impact on the level of stress he experiences. When an athlete with a disability, especially those undergoing training camps, can organize his soul, feelings, and carcass, he will be able to manage the stress he experienced while undergoing training camp. The level of Emotional Intelligence will also affect the performance and stability of athletes with disabilities in actualizing it in training because if the level of Emotional Intelligence is high, it will affect performance in training. This will also have an impact on an athlete with visual disabilities, both on himself and his team. But if on the other hand, Emotional Intelligence is at a moderate to low level, this will damage the athlete's performance and of course will have an impact on the team.

2. Relationship and Contribution or Effect of Hardiness on Stress Resistance

Based on the results of data analysis obtained between the Hardiness variable and stress resistance, the correlation between athletes with visual disabilities and the tendency to Totally Blind is 0.638 with a significance value of 0.001 . It was concluded that hardiness and stress endurance in totally blind athletes had a significant relationship. For the partial contribution or influence, it is indicated by the amount of $\mathrm{r}$ square (r2) which is 0.407 or $40.70 \%$. The linear regression coefficient value shows the value of 1.457 with a positive sign, meaning that if there is an increase in the Hardiness variable it will increase stress resistance by 1.457. So it can be concluded that the research hypothesis is accepted.

The results of data analysis obtained between the variable Hardiness and Stress Endurance, in athletes with visual disabilities with Low Vision tendencies, the correlation results are 0.638 with a significance value of 0.001. It can be concluded that Hardiness and stress endurance in Low Vision athletes has a significant relationship. For the partial contribution or influence, it is indicated by the amount of $\mathrm{r}$ square ( $\mathrm{r} 2)$ obtained by 0.329 or $32.90 \%$. The linear regression coefficient value shows the value of 0.442 with a positive sign, meaning that if there is an increase in the Hardiness variable it will increase stress resistance by 0.442 . So that the overall hypothesis in this study is accepted.

The results of the data analysis in this study indicate that one of the aspects of personality that is possessed, namely Hardiness, has a role or is an element that is no less important in the stress resistance of athletes with visual disabilities. Hardiness is needed so that someone is persistent never to give up and not lose to the situation. Because athletes with visual disabilities who are undergoing training camp are prone to experiencing stress, there is a need for more ability from the aspect of their personality to maintain their best capacity, in this case, for example, changing negative stressors to positive ones. So that it will greatly affect the psychological health of athletes with visual disabilities because if psychological health is affected, the opportunity for an athlete with visual disabilities to be able to fight and survive will be greater. This will have an impact on his career opportunities, where during his training camp is relatively long, it is necessary to have seriousness, endurance, and strength to be able to deal with the fluctuations of events that occur daily so that it will keep him away from degradation.

3. Relationship and Contribution or the Influence of Emotional Intelligence and Hardiness on Stress Resistance. Based on the results of multiple linear analysis between Emotional Intelligence (X1) and Hardiness (X2) on Stress Resistance (Y) in blind athletes with a Totally Blind tendency, the results obtained r square (r2) of 0.495 with a significance value of 0.002 which is less than 0.05 . Contribution or influence is given together or simultaneously, which is 49.50 or $49.5 \%$. These results, also explain that Emotional Intelligence (X1) and Hardiness (X2), with each of the criteria and aspects that are shared, have a role to support an athlete with visual disabilities with a tendency to Total Blind in increasing Stress Resistance. And the remaining 50.5\% of the results that have been obtained are other factors that have not been discussed in this study. Overall it can be concluded, that the study between Emotional Intelligence (X1) and Hardiness (X2) on Stress Resistance (Y) in athletes with visual disabilities with a tendency to Totally Blind, shows a positive and significant relationship, as well as the contribution of each independent variable. Namely, Emotional Intelligence (X1) affects the dependent variable, namely stress resistance. In the end, the hypothesis in this study was accepted. 
The results of multiple linear analysis between Emotional Intelligence (X1) and Hardiness (X2) on Stress Resistance (Y) in blind athletes with Low Vision tendencies, the results obtained r square ( $\mathrm{r} 2$ ) of 0.420 with a significance value of 0.001 which is less than 0.05 . Contribution or influence is given together or simultaneously, which is 42.00 or $42 \%$. These results, also explain that Emotional Intelligence (X1) and Hardiness (X2), with each of the criteria and aspects that are shared, have a role to support a blind athlete with a tendency to Low Vision in increasing Stress Resistance. And the remaining 58\% of the results that have been obtained, are other factors that have not been discussed in this study.

Overall it can be concluded, that the study between Emotional Intelligence (X1) and Hardiness (X2) on Stress Resistance (Y) in athletes with visual disabilities with a tendency to Totally Blind, shows a positive and significant relationship, as well as the contribution of each independent variable. Namely, Emotional Intelligence (X1) affects the dependent variable, namely stress resistance. In the end, the hypothesis in this study was accepted.

From the research results obtained and described as in the previous articles, it shows that the overall elements of each Emotional Intelligence and Hardiness variable, both those possessed by blind athletes with a tendency to Totally Blind or Low Vision, influence the level of Stress Resistance. So that an athlete with visual disabilities can understand, then maximize each capacity of psychological factors and personality aspects to achieve maximum performance.

\section{Conclusion}

As the results of the data analysis that have been carried out and the description of the discussion, as a whole, it can be concluded that:

1) There is no relationship between Emotional Intelligence (X1) and Stress Resistance (Y), in Athletes with Disabilities with a Totally Blind Tendency, indicated by a correlation value of 0.450 with p.value or a significance of 0.062 . However, it gives an effective contribution by showing the value of $\mathrm{r}$ square $(\mathrm{r} 2)$ of 0.180 or $18 \%$ to stress resistance.

2) There is a positive and significant relationship between Emotional Intelligence (X1) and Stress Resistance (Y), in Athletes with Disabilities with Low Vision Tendency, indicated by a correlation value of 0.568 with p.value or a significance of 0.001 . With an effective contribution of $32.23 \%$, it is shown that the $\mathrm{r}$ square ( $\mathrm{r} 2)$ value obtained is 0.322 for stress resistance.

3) There is a positive and significant relationship between Hardiness (X2) and Stress Resistance (Y), in Athletes with Disabilities with a Totally Blind Tendency, indicated by a correlation value of 0.638 with p.value or a significance of 0.002 . With an effective contribution of $40.70 \%$, the value of $r$ square $(\mathrm{r} 2)$ obtained is 0.407 for stress resistance.

4) There is a positive and significant relationship between Hardiness (X2) and Stress Resistance (Y), in Athletes with Disabilities with Low Vision Tendency, with a correlation value of 0.573 with p.value or a significance of 0.001 . With an effective contribution of $32.90 \%$, it is shown that the value of $r$ square ( $r 2$ ) is 0.329 for stress resistance.

5) There is a positive and significant relationship simultaneously between Emotional Intelligence (X1) and Hardiness (X2) with Stress Resistance (Y), in athletes with blind disabilities with a tendency to Totally Blind as evidenced by the acquisition of $r$ square ( $r 2$ ) results of 0.495 with a significance value 0.002 which is less than 0.05 . Contribution or influence has given together or simultaneously, which is 49.50 or $49.5 \%$, then the remaining $50.5 \%$ of the results that have been obtained, are other factors that affect stress resistance.

There is a positive and significant relationship simultaneously between Emotional Intelligence (X1) and Hardiness (X2) with Stress Resistance (Y), in Athletes with Disabilities with Low Vision as evidenced by the acquisition of $r$ square (r2) results of 0.420 with a significance value 0.001 which is less than 0.05 . Contribution or influence has given together or simultaneously, namely 42.00 or $42 \%$, then the remaining $58 \%$ of the results that have been obtained, are other factors that affect stress resistance

\section{Acknowledgments}

I thank My almamater Sebelas Maret University, Slamet Riyadi. As the head of the sports science study program, Agus Kristiyanto and Hanik Likustyawati, as a lecturer who has given good advice and guidance. 
References

Blumenstein, B., \& Orbach, I. (2015). Psychological preparation for Paralympic athletes: A preliminary study. Adapted physical activity quarterly, 32(3), 241-255.

Byers, T. (Ed.). (2015). Contemporary issues in sport management: A critical introduction. Sage.

Dehghansai, N., Lemez, S., Wattie, N., \& Baker, J. (2017). A systematic review of influences on development of athletes with disabilities. Adapted physical activity quarterly, 34(1), 72-90.

Delahaij, R., Gaillard, A. W., \& van Dam, K. (2010). Hardiness and the response to stressful situations: Investigating mediating processes. Personality and Individual differences, 49(5), 386-390. https://doi.org/10.1016/j.paid.2010.04.002

DePauw, K. P. (1986). Research on sport for athletes with disabilities. Adapted physical activity quarterly, 3(4), 292299.

Filaire, E., Larue, J., \& Rouveix, M. (2011). Eating behaviours in relation to emotional intelligence. International journal of sports medicine, 32(4), 309.

Fitzgerald, H. (2012). Paralympic athletes and "knowing disability". International Journal of Disability, Development and Education, 59(3), 243-255.

Goss, J. D. (1994). Hardiness and mood disturbances in swimmers while overtraining. Journal of Sport and Exercise Psychology, 16(2), 135-149.

Hanrahan, S. J. (2015). Psychological skills training for athletes with disabilities. Australian Psychologist, 50(2), 102-105.

Holder, M. (2015). The Special Olympics healthy athletes experience. Current sports medicine reports, 14(3), 165170.

Hutzler, Y., Oz, M., \& Barak, S. (2013). Goal perspectives and sport participation motivation of Special Olympians and typically developing athletes. Research in developmental disabilities, 34(7), 2149-2160. https://doi.org/10.1016/j.ridd.2013.03.019

Lane, A. M., \& Wilson, M. (2011). Emotions and trait emotional intelligence among ultra-endurance runners. Journal of Science and Medicine in Sport, 14(4), 358-362. https://doi.org/10.1016/j.jsams.2011.03.001

Lu, F. J., Li, G. S. F., Hsu, E. Y. W., \& Williams, L. (2010). Relationship between athletes' emotional intelligence and precompetitive anxiety. Perceptual and motor skills, 110(1), 323-338.

MacDonald, D. J., Beck, K., Erickson, K., \& Côté, J. (2016). Understanding sources of knowledge for coaches of athletes with intellectual disabilities. Journal of Applied Research in Intellectual Disabilities, 29(3), 242-249.

Madden, R. F., Shearer, J., \& Parnell, J. A. (2017). Evaluation of dietary intakes and supplement use in paralympic athletes. Nutrients, 9(11), 1266.

McLoughlin, G., Fecske, C. W., Castaneda, Y., Gwin, C., \& Graber, K. (2017). Sport participation for elite athletes with physical disabilities: Motivations, barriers, and facilitators. Adapted Physical Activity Quarterly, 34(4), 421441.

Orbell, S., Schneider, H., Esbitt, S., Gonzalez, J. S., Gonzalez, J. S., Shreck, E., Batchelder, A., Gidron, Y., Pressman, S. D., Hooker, E. D., Wiebe, D. J., Rinehart, D., Hayman, L. L., Meneghini, L., Kikuchi, H., Kikuchi, H., Desouky, T. F., McAndrew, L. M., Mora, P. A., ... Turner, J. R. (2013). Hardiness. In Encyclopedia of Behavioral Medicine.

Palmer, B., Donaldson, C., \& Stough, C. (2002). Emotional intelligence and life satisfaction. Personality and individual differences, 33(7), 1091-1100. https://doi.org/10.1016/S0191-8869(01)00215-X

Petrides, K. V., \& Furnham, A. (2000). On the dimensional structure of emotional intelligence. Personality and individual differences, 29(2), 313-320. https://doi.org/10.1016/S0191-8869(99)00195-6

Salim, J., Wadey, R., \& Diss, C. (2015). Examining the relationship between hardiness and perceived stress-related growth in a sport injury context. Psychology of Sport and exercise, 19, 10-17. https://doi.org/10.1016/j.psychsport.2014.12.004

Shapiro, D. R., \& Martin, J. J. (2010). Athletic identity, affect, and peer relations in youth athletes with physical disabilities. Disability and health journal, 3(2), 79-85. https://doi.org/10.1016/j.dhjo.2009.08.004

Shapiro, D. R., \& Martin, J. J. (2014). The relationships among sport self-perceptions and social well-being in athletes with physical disabilities. Disability and health journal, 7(1), 42-48. https://doi.org/10.1016/j.dhjo.2013.06.002

Sheard, M., \& Golby, J. (2010). Personality hardiness differentiates elite-level sport performers. international Journal oF sport and exercise psychology, 8(2), 160-169. 